\title{
ANALISIS DETERMINAN DAN PENGARUH STUNTING TERHADAP PRESTASI BELAJAR ANAK SEKOLAH DI KUPANG DAN SUMBA TIMUR, NTT
}

\author{
(The Determinant Analysis and the Impact of Stunting for School Children School Performance in \\ Kupang and Sumba Timur, NTT)
}

Intje Picauly ${ }^{1}$ dan Sarci Magdalena Toy ${ }^{1}$

1Jurusan Gizi Kesehatan Masyarakat, Fakultas Kesehatan Masyarakat, Universitas Nusa Cendana, Jl. Jenderal Soeharto. No. 72 Naikoten I, Kupang, NTT

\begin{abstract}
The research was conducted to find out determinant factors that can cause the incidence of stunting and how it may affect elementary school children performance. The research areas were selected based on the difference access of nutrition information. Kabupaten Sumba Timur and Kota Kupang were selected as research areas. Related primary data was taken covering anthropometric index namely body height for age (HFA); weight for age (WFA), and weight for height (WFH), and academic school performances before and after research treatment. Other data was collected by interview using questionnaires. Regression analysis was used to know determinant factors that may bring about stunting. The results showed that determinant factors of stunting were family income, mother's nutrition knowledge, child care practices, the history of infection, immunization, protein intake, and mother education. While, stunted elementary school children had low academic performances. The higher level of stunting is the lower academic performance of elementary school children.
\end{abstract}

Keywords: academic performances, determinant of Stunting, elementary school students

\begin{abstract}
ABSTRAK
Penelitian ini bertujuan untuk mengetahui faktor-faktor yang berhubungan dengan kejadian stunting serta dampaknya terhadap prestasi anak sekolah dasar. Penelitian dilakukan di Kota Kupang dan Kabupaten Sumba Timur. Lokasi penelitian sengaja diambil dua wilayah yang berbeda jangkauan informasi tentang gizi dan manfaatnya serta ketersediaan sarana prasarana yang dapat digunakan untuk pencapaian kondisi bebas masalah gizi. Subjek yang dibutuhkan dalam penelitian ini masing-masing sebanyak 265 siswa di Kota Kupang dan 274 di Kabupaten Sumba Timur. Adapun jenis data yang digunakan adalah data primer yang meliputi data indeks antropometri (TB/U; BB/U; BB/TB) dan data hasil pengukuran nilai siswa. Selain itu data-data lain dilengkapi dan diukur menggunakan instrumen kuesioner yang bersifat terstruktur. Analisis determinan menggunakan jenis analisis regresi logistik. Hasil penelitian menunjukkan bahwa faktor-faktor determinan stunting adalah faktor pendapatan keluarga, pengetahuan gizi ibu, pola asuh ibu, riwayat infeksi penyakit, riwayat imunisasi, asupan protein dan pendidikan ibu. Siswa yang stunting lebih banyak memiliki prestasi belajar yang kurang, sementara siswa yang non stunting lebih banyak memiliki prestasi belajar yang baik.
\end{abstract}

Kata kunci: anak sekolah dasar, determinan stunting, prestasi belajar

"Korespondensi: Jurusan Gizi Kesehatan Masyarakat, Fakultas Kesehatan Masyarakat, Universitas Nusa Cendana, Jl. Jenderal Soeharto. No. 72 Naikoten I, Kupang, NTT, Telp/Faks: (0380-821410); 081353801455. Email: picaulyince@yahoo.co.id 


\section{PENDAHULUAN}

Stunting adalah bentuk dari proses pertumbuhan anak yang terhambat. Sampai saat ini stunting merupakan salah satu masalah gizi yang perlu mendapat perhatian. Prevalensi nasional untuk kurang gizi kronis (stunting) berdasarkan hasil Riset Kesehatan Dasar (Riskesdas) tahun 2010 pada anak usia 6-12 tahun sebesar 35.6\%, angka ini tergolong tinggi untuk tingkatan kesehatan masyarakat. Sementara untuk tingkat nasional, provinsi Nusa Tenggara Timur menempati urutan pertama prevalensi stunting tertinggi yakni sebesar $58.4 \%$. Dengan demikian, masalah gizi kronis (stunting) masih tetap tinggi di provinsi NTT.

Sumba Timur dan Kota Kupang merupakan dua wilayah yang secara administrasi memiliki perbedaan yang nyata. Kota Kupang memiliki kelebihan dalam beberapa hal seperti memiliki sumber informasi, pusat pendidikan, dan keragaman pangan jauh lebih baik dan lengkap dikarenakan wilayah tersebut adalah ibu kota propinsi sedangkan Sumba Timur merupakan wilayah administrasi Kabupaten.

Hasil Rekapitulasi Pemantauan Status Gizi (PSG) diketahui bahwa persentase stunting di Kota Kupang sebesar $63.3 \%$ dan Sumba Timur sebesar 42.3\%. Angka itu memberi gambaran bahwa lebih dari sepertiga anak di Kota Kupang dan Kabupaten Sumba Timur berperawakan pendek dibandingkan dengan tinggi badan yang seharusnya mereka capai pada usia tersebut.

Rekomendasi dari berbagai hasil penelitian sebelumnya menyimpulkan bahwa hambatan pertumbuhan anak dipengaruhi oleh berbagai faktor. Baker (2008) menambahkan bahwa faktor yang dapat berpengaruh adalah faktor lingkungan dan genetik serta interaksi keduanya. Oleh karena itu untuk menyusun langkah nyata dalam penanggulangan masalah gizi khusus pada kelompok balita dan anak usia sekolah dasar diperlukan kajian tentang faktor determinan dan dampak terjadinya masalah gizi tersebut terhadap kualitas sumberdaya manusia Indonesia. Berdasarkan hal tersebut maka peneliti tertarik untuk melakukan penelitian dengan tujuan untuk menganalisis determinan dan pengaruh stunting terhadap prestasi belajar anak sekolah di Kota Kupang dan Sumba Timur, Propinsi Nusa Tenggara Timur.

\section{METODE}

\section{Desain, Tempat, dan Waktu}

Jenis penelitian ini adalah survai analitik dengan menggunakan desain cross sectional. Penelitian ini berlangsung dari Bulan Maret-Desember 2012. Lokasi penelitian adalah Kota Kupang dan Kabupaten Sumba Timur, Provinsi Nusa Tenggara Timur. Dengan menggunakan data persentase kasus gizi buruk tertinggi maka secara purposive sampling terpilih dari masing-masing wilayah adalah Kecamatan Pasir Panjang, Kota Kupang dan Kecamatan Waingapu, Kabupaten Sumba Timur.

\section{Jumlah dan Cara Penarikan Subjek}

Populasi dalam penelitian ini adalah semua anak sekolah dasar yang bersekolah di wilayah Kecamatan Pasir Panjang berjumlah 1250 siswa dan Wilayah Kecamatan Waingapu berjumlah 1356 siswa. Dengan mempertimbangkan jumlah populasi dan penentuan jumlah subjek menggunakan persamaan dari Soekidjo Notoatmodjo (2005) dan Saryono (2009) maka jumlah subjek yang dibutuhkan dalam penelitian ini masing-masing sebanyak 265 siswa di Kota Kupang dan 274 di Kabupaten Sumba Timur.

\section{Jenis dan Cara Pengumpulan Data}

Data primer yang dikumpulkan adalah data pendidikan dan pekerjaan orang tua, umur, data tinggi badan siswa yang diukur dengan menggunakan microtoise dengan ketelitian $0.1 \mathrm{~cm}$; data keragaman pangan diperoleh melalui metode Food Frequency Questionnaires (FFQ); data riwayat infeksi penyakit, status sosial ekonomi, pola asuh, riwayat imunisasi, diperoleh melalui observasi dan wawancara dengan menggunakan kuesioner. Data prestasi belajar siswa didapatkan dari nilai rata-rata ulangan harian untuk mata pelajaran matematika (mewakili bidang IPA) dan mata pelajaran bahasa Indonesia (mewakili bidang IPS dan Bahasa) dengan kriteria baik (7.0-10); cukup (5.5-6.9), dan kurang (<5.5). Data sekunder diperoleh dari Sekolah Dasar, Puskesmas dan Dinas Kesehatan di Wilayah Kota Kupang dan Sumba Timur.

\section{Pengolahan dan Analisis Data}

Menurut Riyanto (2012) analisis determinan kejadian stunting dilakukan dengan menggunakan uji statistik regresi logistik berganda pada tingkat kemaknaan 95\% ( $a=0.05$ ). Kemudian untuk mengetahui pengaruh stunting terhadap prestasi belajar menggunakan uji statistik regresi linier sederhana pada tingkat kemaknaan 95\% ( $a=0.05)$.

\section{HASIL DAN PEMBAHASAN}

\section{Karakteristik Sosial Ekonomi Keluarga Subjek}

Riyadi dkk (2006) dan Astari dkk (2006) mengatakan bahwa ciri rumah tangga anak stunted adalah pendapatan dan pengeluaran untuk pangan yang rendah serta terdapatnya perbedaan yang nyata $(p<0.05)$ pada tingkat pendidikan orang tua antara kelompok anak stunting dan kelompok anak normal. Kemudian Depkes RI (2008) menyimpulkan bahwa selain faktor kurangnya ketersediaan pangan, status gizi juga dapat dipengaruhi oleh faktor kondisi sosial ekonomi dan budaya keluarga. Dalam 
penelitian ini, indikator sosial ekonomi diukur melalui indikator pendidikan, pendapatan, pengetahuan informal, dan status pekerjaan ibu keluarga.

Hasil penelitian ini sejalan dengan hasil penelitian yang dilakukan oleh Nasikhah dan Margawati (2012) yang mengatakan bahwa tinggi badan orang tua yang pendek, tingkat pendidikan orang tua yang rendah, dan tingkat pendapatan orang tua yang rendah serta status ibu balita (bekerja dan tidak bekerja) merupakan faktor risiko yang berpengaruh terhadap kejadian stunting. Sedangkan ditemukan bahwa faktor pengetahuan gizi ibu subjek tidak menjadi faktor risiko stunting. Hal ini berarti bahwa walaupun persentase ibu subjek yang mempunyai tingkat pengetahuan gizi baik namun tidak menjamin untuk bebas dari stunting.

Tabel 1 menunjukkan bahwa latar belakang karakteristik sosial ekonomi keluarga subjek masih cukup memuaskan walaupun dari segi tingkat pendapatan di Kabupaten Sumba Timur masih rendah. Hal ini disebabkan karena sebagian besar keluarga bekerja di sektor swasta dan pertanian dengan jenis pendapatan harian, musiman, dan bahkan tidak menentu. Selain itu diduga bahwa tingginya tingkat pendidikan dan pengetahuan gizi ibu tidak didukung oleh faktor sikap dan tindakan. Hal ini disebabkan karena sebagian besar (>95\%) ibu subjek lebih banyak mengalokasikan waktu diluar rumah sehingga cenderung mengabaikan pola asuh gizi yang tepat pada anak.

Tabel 1. Distribusi Subjek berdasarkan Karakteristik Sosial Ekonomi Keluarga

\begin{tabular}{lcccc}
\hline & \multicolumn{2}{c}{$\begin{array}{c}\text { Kota } \\
\text { Indikator Sosek }\end{array}$} & \multicolumn{2}{c}{ Kab. Sumba } \\
& $\mathrm{n}$ & $\%$ & $\mathrm{n}$ & $\%$ \\
\hline Pendapatan Keluarga: & & & & \\
Tinggi ( $\geq$ Rp 800 000) & 87 & 32.83 & 95 & 34.67 \\
Rendah (<Rp 800 000) & 178 & 67.17 & 179 & 65.33 \\
Pendidikan Ibu: & & & & \\
$\quad$ Tinggi ( $\geq 9$ tahun) & 198 & 74.72 & 177 & 64.60 \\
$\quad$ Rendah (<9 tahun) & 67 & 25.28 & 97 & 35.40 \\
Pengetahuan Gizi Ibu: & & & & \\
Baik (>80\%) & 205 & 77.36 & 222 & 81.02 \\
Cukup (60-80\%) & 60 & 22.64 & 47 & 17.15 \\
Kurang (<60\%) & 0 & 00 & 5 & 1.83 \\
Status Pekerjaan Ibu: & & & & \\
Bekerja & 262 & 98.87 & 262 & 95.62 \\
Tidak Bekerja & 3 & 1.13 & 12 & 4.38 \\
\hline
\end{tabular}

\section{Asupan dan Status Gizi Subjek}

Masa anak-anak adalah masa pertumbuhan, untuk itu anak memerlukan asupan gizi yang cukup. Asupan gizi yang tepat bagi anak harus tepat dan seimbang. Gambaran asupan gizi subjek dapat dilihat pada Tabel 2.
Tabel 2. Distribusi Subjek berdasarkan Asupan Gizi menurut Wilayah Penelitian

\begin{tabular}{|c|c|c|c|c|}
\hline \multirow[t]{2}{*}{ Asupan Gizi } & \multicolumn{2}{|c|}{$\begin{array}{c}\text { Kota } \\
\text { Kupang }\end{array}$} & \multicolumn{2}{|c|}{$\begin{array}{c}\text { Kab. Sumba } \\
\text { Timur }\end{array}$} \\
\hline & $\mathrm{n}$ & $\%$ & $\mathrm{n}$ & $\%$ \\
\hline \multicolumn{5}{|l|}{ Asupan Energi: } \\
\hline Baik (>80\%AKG) & 205 & 77.36 & 222 & 81.02 \\
\hline Kurang (<70-80\%AKG) & 60 & 22.64 & 52 & 18.98 \\
\hline \multicolumn{5}{|l|}{ Asupan Protein: } \\
\hline Baik (>80\%AKG) & 78 & 29.43 & 95 & 34.67 \\
\hline Kurang (<70-80\%AKG) & 187 & 70.57 & 179 & 65.33 \\
\hline
\end{tabular}

Tabel di atas menunjukkan bahwa sebagian besar subjek memiliki asupan zat gizi protein dalam kategori kurang (65-71\%). Jika dihubungkan dengan indikator pendapatan (Tabel 1) diketahui bahwa kondisi inilah yang memperburuk peluang terpenuhinya kebutuhan zat gizi dimaksud. Riyadi et al. (2006) mengatakan bahwa jenis dan jumlah pangan yang dikonsumsi kelompok anak normal lebih beragam dan banyak dibanding kelompok anak yang stunting. Oleh karena itu, kontribusi protein terhadap AKG pada kelompok anak normal lebih tinggi dibanding kelompok anak stunting.

Tabel 3 menjelaskan bahwa masalah stunting pada dua wilayah penelitian telah melebihi batas ambang penerimaan derajat kesehatan masyarakat (10\%) yaitu sebesar $25-31.75 \%$. Hal ini menandakan bahwa adanya permasalahan yang serius dalam proses peningkatan kualitas sumberdaya manusia. Hasil penelitian Mahgoub et al. (2006) sejalan dengan hasil penelitian dari Lana et al. (2012) dan Kusumaningrum et al. (2013) yang menunjukkan bahwa masalah kekurangan pangan serta masalah gizi yang berkepanjangan dapat memengaruhi kualitas Balita khususnya di Kabupaten Timor Tengah Selatan (TTS). Namun dengan upaya perbaikan dengan metode pendekatan Positive Deviance (PD) Pos Gizi yang lebih baik maka permasalah gizi dapat tertanggulangi.

Tabel 3. Distribusi Subjek berdasarkan Kategori Stunting dan Non Stunting menurut Wilayah Penelitian

\begin{tabular}{lcccc}
\hline \multirow{2}{*}{ Status Gizi (TB/U) } & \multicolumn{2}{c}{$\begin{array}{c}\text { Kota } \\
\text { Kupang }\end{array}$} & \multicolumn{2}{c}{ Kab. Sumba } \\
& Timur \\
\cline { 2 - 5 } & $\mathbf{n}$ & $\%$ & $\mathbf{n}$ & $\%$ \\
\hline Stunting & 68 & 25.66 & 87 & 31.75 \\
Non stunting & 197 & 74.34 & 187 & 68.25 \\
\hline
\end{tabular}

\section{Indikator Lainnya}

Peran keluarga terutama ibu dalam mengasuh anak akan menentukan tumbuh kembang anak (Husaini et al. 2000). Sawadogo et al. (2006) menyatakan bahwa perilaku ibu dalam menyusui atau memberi makan, cara makan yang sehat, memberi makanan yang bergizi dan mengontrol 
besar porsi yang dihabiskan akan meningkatkan status gizi anak. Lebih lanjut Setiati (2006) mengatakan bahwa faktor-faktor yang memengaruhi pola asuh adalah pendidikan, pekerjaan, umur dan tingkat pengetahuan ibu. Kenyataan tersebut tidak berbeda dengan kasus pada wilayah Kota Kupang dan Kabupaten Sumba Timur (Tabel 4). Namun berdasarkan hasil wawancara dengan subjek diketahui bahwa dalam penerapan pola asuh masih terbatas pada aspek perilaku ibu dalam menyusui atau memberi makan, cara makan yang sehat, memberi makanan yang bergizi dan mengontrol besar porsi yang dihabiskan. Hal ini disebabkan karena keterbatasan waktu yang disediakan di rumah bersama anak.

Tabel 4. Distribusi Subjek berdasarkan Kategori Stunting dan Non Stunting menurut Wilayah Penelitian

\begin{tabular}{|c|c|c|c|c|}
\hline \multirow[t]{2}{*}{ Indikator Lainnya } & \multicolumn{2}{|c|}{$\begin{array}{c}\text { Kota } \\
\text { Kupang }\end{array}$} & \multicolumn{2}{|c|}{$\begin{array}{c}\text { Kab. Sumba } \\
\text { Timur }\end{array}$} \\
\hline & $\mathrm{n}$ & $\%$ & $\mathrm{n}$ & $\%$ \\
\hline \multicolumn{5}{|c|}{ Riwayat Infeksi Penyakit: } \\
\hline Tidak ada & 96 & 36.23 & 93 & 33.94 \\
\hline Ada & 169 & 63.77 & 181 & 66.06 \\
\hline \multicolumn{5}{|l|}{ Pola Asuh Ibu: } \\
\hline Baik (>80\%) & 76 & 28.68 & 89 & 32.48 \\
\hline Cukup (60-80\%) & 125 & 47.17 & 112 & 40.87 \\
\hline Kurang (<60\%) & 64 & 24.15 & 73 & 26.65 \\
\hline Riwayat Imunisasi: & 205 & 77.36 & 222 & 81.02 \\
\hline Lengkap & 105 & 39.62 & 99 & 36.13 \\
\hline Belum lengkap & 160 & 60.38 & 170 & 62.05 \\
\hline Tidak pernah & 0 & 0.00 & 5 & 1.82 \\
\hline
\end{tabular}

Hal yang sama juga ditekankan oleh Renyoet et al. (2012) dalam hasil penelitiannya yang mengemukan bahwa adanya hubungan yang signifikan antara perhatian/dukungan ibu terhadap anak dalam praktek pemberian makanan, rangsangan psikososial, kebersihan/hygiene dan sanitasi lingkungan dan pemanfaatan pelayanan kesehatan dengan kejadian stunting anak $(\mathrm{p}<0.05)$.

Hasil penelitian ini sejalan dengan yang ditemukan dalam hasil penelitian Nubatonis et al. (2012) yang menunjukkan bahwa pola pengasuhan asuh lebih berat pada rendahnya pola hidup bersih dan sehat.

Hasil penelitian Nasikhah dan Margawati (2012) juga menunjukkan bahwa faktor riwayat penyakit infeksi, frekuensi sakit diare dan jumlah anggota keluarga tidak menjadi faktor risiko stunting. Sehingga dapat diperkirakan bahwa ada atau tidaknya kasus penyakit infeksi tidak berpengaruh pada peluang terjadinya stunting. Kasus penyakit infeksi yang lebih sering diderita oleh subjek adalah infeksi saluran pernapasan, demam berdarah, dan diare.

\section{Analisis Determinan Stunting}

Analisis multivariat bertujuan untuk menentukan variabel yang paling dominan dalam memengaruhi kejadian stunting. Hasil analisis regresi logistik sederhana menunjukkan bahwa semua variabel memiliki nilai $p<0.25$ kecuali variabel asupan energi yang memiliki nilai $p>0.25$ (Tabel 5). Hal ini berarti bahwa variabel pendapatan keluarga, pendidikan ibu, pengetahuan gizi ibu, pekerjaan ibu, asupan protein, riwayat penyakit infeksi, pola asuh ibu, dan riwayat imunisasi berpengaruh signifikan terhadap terjadinya stunting sedangkan variabel asupan energi tidak memengaruhi kejadian stunting.

Hasil analisis lanjutan menunjukkan bahwa variabel yang lebih berpengaruh terhadap kejadian stunting pada anak adalah variabel pendapatan keluarga dengan nilai Odds Ratio Adjusted tertinggi yaitu 62.128. Model regresi logistik yang terbentuk dalam analisis ini adalah:

$$
\begin{aligned}
\operatorname{logit}(p)= & -11.639+4.129 \times 1-3.022 \times 2+3.264 \times 3+ \\
& 3.623 \times 4+1.926 \times 6+2.332 \times 7+2.827 \times 8+ \\
& 1.983 \times 9
\end{aligned}
$$

Melalui model ini dapat diketahui bahwa determinan lain secara bersama-sama berpengaruh

Tabel 5. Hasil Analisis Multivariat Regresi Logistik Ganda Sembilan Variabel yang Berhubungan Bermakna dengan Kejadian Stunting

\begin{tabular}{lcccc}
\hline \multicolumn{1}{c}{ Variabel Independen } & B & P & OR (Adjusted) & Cl 95\% \\
\hline Pendapatan Keluarga (X1) & 4.129 & 0.011 & 62.128 & $2.541-1.519 \mathrm{E} 3$ \\
Pendidikan Ibu (X2) & -3.022 & 0.009 & 0.049 & $0.005-0.466$ \\
Pengetahuan Gizi Ibu (X3) & 3.264 & 0.032 & 26.152 & $1.324-516.753$ \\
Pekerjaan Ibu (X4) & 3.623 & 0.017 & 37.445 & $1.891-741.531$ \\
Asupan Energi (X5) & 1.587 & 0.208 & 4.888 & $0.413-57.879$ \\
Asupan Protein (X6) & 1.926 & 0.044 & 6.863 & $1.056-44.606$ \\
Riwayat Infeksi (X7) & 2.332 & 0.023 & 10.298 & $1.388-76.398$ \\
Pola Asuh Ibu (X8) & 2.827 & 0.026 & 16.893 & $1.404-203.294$ \\
Riwayat Imunisasi (X9) & 1.983 & 0.027 & 7.264 & $1.256-42.014$ \\
\hline
\end{tabular}


terhadap kejadian stunting adalah pendapatan keluarga, pendidikan ibu, pengetahuan gizi ibu, ibu yang bekerja, asupan protein kurang, ada riwayat infeksi penyakit, pola asuh ibu kurang, dan tidak ada riwayat imunisasi.

Hasil analisis regresi logistik menunjukkan bahwa keluarga dengan tingkat pendapatan rendah memiliki peluang anaknya mengalami stunting sebesar 62.128 kali lebih besar dibandingkan keluarga dengan tingkat pendapatan tinggi. Hal ini sesuai dengan hasil penelitian Riyadi et al. (2006), Zottareli et al. (2007), Salimar (2009), dan Aditianti (2010) yang menyatakan bahwa tingkat ekonomi berpengaruh signifikan terhadap stunting pada balita. Atau, status sosial ekonomi dapat mendeterminasi kejadian stunting pada anak.

Hasil analisis regresi logistik menunjukkan bahwa ibu dengan tingkat pendidikan rendah memiliki peluang anaknya mengalami stunting sebesar 0.049 kali lebih besar dibandingkan ibu dengan pendidikan tinggi. Hal ini berarti bahwa jika pendidikan ibu tinggi maka akan diikuti dengan penurunan kejadian stunting sebesar 3.022. Namun, kenyataan yang dijumpai adalah tidak semua ibu yang berpendidikan tinggi memiliki pengetahuan gizi dan pola pengasuhan yang baik, atau sebaliknya. Data pada Tabel 1 dan 4 menunjukkan bahwa sebagian besar (>60\%) ibu subjek mempunyai tingkat pendidikan dan pengetahuan gizi dengan kategori Baik. Sedangkan sekitar $28.68-32.48 \%$ ibu subjek mempunyai pola asuh dalam kategori cukup. Hasil penelitian ini sejalan dengan kenyataan yang ditemukan oleh Oematan et al. (2013) bersama peneliti sebelumnya seperti Yustika (2006), Semba et al. (2008) dan Ramli et al. (2009) yang mengatakan bahwa tingkat pendidikan formal dan pengetahuan gizi ibu sangat berpengaruh pada peluang terjadinya stunting.

Hasil analisis regresi logistik menunjukkan bahwa ibu yang bekerja memiliki peluang anaknya mengalami stunting lebih besar dibandingkan ibu yang tidak bekerja. Hal ini berarti bahwa jika ibu bekerja maka akan diikuti dengan peningkatan kejadian stunting sebesar 3.623. Berg (1986) mengatakan bahwa ibu-ibu yang bekerja tidak mempunyai cukup waktu untuk memperhatikan makanan anak yang sesuai dengan kebutuhan dan kecukupan serta kurang perhatian dan pengasuhan kepada anak.

Hal ini memberikan gambaran bahwa tingkat pendidikan dan pengetahuan gizi tidak menjamin untuk memiliki pola asuh yang baik. Zere dan McIntyre (2003), Sawadogo et al. (2006), dan Astri et al. (2006) mengatakan bahwa ibu yang memiliki interval waktu lebih banyak di luar untuk bekerja tidak dapat mengontrol pola konsumsi pangan anak dengan baik. Hal ini berimplikasi pada asupan gizi anak yang tidak berimbang. Walaupun demikian, tingkat pendidikan yang tinggi tetap faktor penting. Sebab semakin tinggi tingkat pendidikan seseorang maka semakin mudah dalam proses penyerapan atau adopsi informasi sehingga diharapkan akan tercipta pola kebiasaan yang baik dan sehat.

Hasil analisis regresi logistik menunjukkan bahwa ibu dengan pengetahuan gizi kurang/rendah, memiliki peluang anaknya mengalami stunting dibandingkan ibu dengan pengetahuan gizi baik. Hal ini berarti bahwa jika pengetahuan gizi ibu kurang maka akan diikuti dengan peningkatan kejadian stunting sebesar 3.264 kali. Hal ini sesuai dengan hasil penelitian Fikhar (2003) yang menyatakan ada hubungan yang bermakna antara tingkat pengetahuan dengan status gizi buruk dengan nilai OR sebesar 3.428. Pengetahuan seorang ibu dibutuhkan dalam perawatan anaknya, dalam hal pemberian dan penyediaan makanannya, sehingga seorang anak tidak menderita kekurangan gizi.

Hasil analisis regresi logistik menunjukkan bahwa faktor asupan energi tidak mempunyai pengaruh yang signifikan terhadap kejadian stunting $(p>0.05)$. Hal ini disebabkan karena sebagian besar (lebih dari 70\%) anak pada kedua kelompok (stunting maupun non stunting) di Wilayah Kota Kupang dan Kabupaten Sumba Timur sama-sama memiliki asupan energi yang baik. Hal ini diperkuat dengan pendapat dari Almatsier (2001) dan hasil penelitian dari Sawadogo et al. (2006) dan Ramli et al. (2009) yang menyatakan bahwa pertumbuhan tinggi badan bisa terhambat bila seorang anak mengalami defisiensi protein (meskipun konsumsi energinya cukup) dalam jangka waktu yang lama, sedangkan bobot badan lebih banyak dipengaruhi oleh cukup tidaknya konsumsi energi.

Hasil analisis regresi logistik menunjukkan bahwa anak dengan asupan protein kurang memiliki peluang mengalami stunting lebih besar dibandingkan anak yang asupan proteinnya baik. Hal ini berarti bahwa jika asupan protein rendah maka akan diikuti dengan peningkatan kejadian stunting sebesar 1.926 kali. Penegasan hal dimaksud juga disampaikan oleh Almatsier (2001) bahwa pertumbuhan tinggi badan anak dapat terhambat bila seorang anak mengalami defisiensi protein (meskipun konsumsi energinya cukup) selama masa seribu hari pertama kehidupan dan berlangsung dalam jangka waktu yang lama (Kusharisupeni 2002), sedangkan bobot badan lebih banyak dipengaruhi oleh cukup tidaknya konsumsi energi.

Hasil analisis regresi logistik menunjukkan bahwa anak yang memiliki riwayat penyakit infeksi memiliki peluang mengalami stunting lebih besar dibandingkan anak yang tidak memiliki riwayat infeksi penyakit. Hal ini berarti bahwa jika anak memiliki riwayat infeksi penyakit maka akan diikuti dengan peningkatan kejadian stunting 2.332 kali. Hasil penelitian ini sejalan dengan hasil penelitian Aditianti (2010) yang menyatakan bahwa penyakit infeksi berpengaruh signifikan terhadap stunting 
pada anak usia 24-59 bulan. Di samping itu, Pujiadji (2000) dalam Supariasa et al. (2002) juga mengatakan bahwa infeksi berat dapat memperburuk keadaan gizi melalui gangguan masukan makanannya dan meningginya kehilangan zat-zat gizi esensial tubuh melalui muntah-muntah dan diare. Selain itu penyakit infeksi seperti infeksi saluran pernapasan dapat juga menurunkan nafsu makan. Sebaliknya malnutrisi walaupun ringan berpengaruh negatif terhadap daya tahan tubuh terhadap infeksi.

Hasil analisis regresi logistik menunjukkan bahwa ibu dengan pola asuh kurang/rendah, memiliki peluang anaknya mengalami stunting lebih besar dibandingkan ibu dengan pola asuh baik. Hal ini berarti bahwa jika pola asuh ibu kurang maka akan diikuti dengan peningkatan kejadian stunting 2.827 kali. Adar et al. (1997), Adisasmito (2007) dan Nubatonis et al. (2012), memperkuat hasil penelitian dengan mengatakan bahwa pola pengasuhan adalah kemampuan keluarga dan masyarakat untuk menyediakan waktu, perhatian, dan dukungan terhadap anak agar dapat bertumbuh dan berkembang dengan sebaik-baiknya secara fisik, mental, dan sosial.

Hasil analisis regresi logistik menunjukkan bahwa anak yang tidak memiliki riwayat imunisasi memiliki peluang mengalami stunting lebih besar dibandingkan anak yang memiliki riwayat imunisasi. Hal ini berarti bahwa jika anak tidak memiliki riwayat imunisasi maka akan diikuti dengan peningkatan kejadian stunting 1.983 kali. Hasil ini sejalan dengan penelitian Salimar (2009) yang menyatakan bahwa kelengkapan imunisasi berpengaruh signifikan terhadap stunting. Imunisasi adalah pemberian kekebalan tubuh terhadap suatu penyakit dengan memasukkan sesuatu ke dalam tubuh agar tubuh tahan terhadap penyakit yang sedang mewabah atau berbahaya bagi seseorang.

\section{Prestasi Belajar}

Prestasi belajar adalah penilaian hasil usaha kegiatan belajar yang dinyatakan dalam bentuk simbol, angka, huruf, maupun kalimat yang dapat mencerminkan hasil yang sudah dicapai oleh setiap anak dalam periode tertentu. Prestasi belajar merupakan hal yang tidak dapat dipisahkan dari kegiatan belajar, karena kegiatan belajar merupakan proses, sedangkan prestasi merupakan hasil dari proses belajar. Prestasi belajar anak sekolah dapat diketahui setelah diadakannya evaluasi. Hasil dari evaluasi dapat memperlihatkan tentang tinggi atau rendahnya prestasi belajar siswa (Ridwan 2008).

Tabel 6 menunjukkan bahwa pada Wilayah Kota Kupang dan Wilayah Kabupaten Sumba Timur memiliki siswa stunting dengan prestasi belajar yang rendah dan sudah melebihi 15\%. Hal ini menandakan bahwa kejadian masalah stunting tidak mempertimbangkan letak wilayah dan faktor-faktor pengganggu lainnya (Fanggi 2012 dan Bora 2012). Dikatakan bahwa prestasi belajar yang rendah tidak mempertimbangkan kondisi stunting atau non stunting. Informasi yang diperoleh dari berbagai pihak seperti orang tua murid dan guru (kelas dan mata pelajaran) dan diperkuat oleh hasil penelitian Semba et al. (2008) dan Yustika (2006) bahwa siswa yang mempunyai prestasi rendah pada umumnya dihadapi dengan dua permasalahan inti yaitu tingginya jumlah absensi serta rendahnya kualitas penyerapan dan penguasaan materi pembelajaran oleh siswa yang stunting.

Depkes (2008) menyampaikan bahwa selain faktor kurangnya ketersediaan pangan, masalah stunting juga dapat dipengaruhi oleh faktor kondisi sosial ekonomi dan budaya keluarga. Sosial ekonomi dapat diukur melalui indikator-indikator seperti pendidikan, pendapatan, pengetahuan informal, dan status pekerjaan ibu keluarga.

Tabel 6. DistribusiSubjek berdasarkan Prestasi Belajar

\begin{tabular}{lcccc}
\hline \multirow{2}{*}{ Prestasi Belajar } & \multicolumn{2}{c}{ Stunting } & \multicolumn{2}{c}{ Non Stunting } \\
\cline { 2 - 5 } & $\mathrm{n}$ & $\%$ & $\mathrm{n}$ & $\%$ \\
\hline Kota Kupang: & & & & \\
$\quad$ Baik ( $\geq 7.0)$ & 25 & 36.76 & 107 & 54.31 \\
$\quad$ Cukup (5.5-6.9) & 15 & 22.06 & 72 & 36.55 \\
$\quad$ Kurang (<5.5) & 28 & 41.18 & 18 & 9.14 \\
Kabupaten Sumba Timur: & & & & \\
$\quad$ Baik ( $\geq 7.0)$ & 10 & 11.49 & 100 & 53.48 \\
$\quad$ Cukup (5.5-6.9) & 61 & 70.12 & 67 & 35.83 \\
$\quad$ Kurang (<5.5) & 16 & 18.39 & 20 & 10.69 \\
\hline
\end{tabular}

\section{Dampak Stunting terhadap Prestasi Belajar}

Stunting merupakan wujud dari adanya gangguan pertumbuhan pada tubuh, bila ini terjadi, maka salah satu organ tubuh yang cepat mengalami risiko adalah otak. Dalam otak terdapat sel-sel saraf yang sangat berkaitan dengan respons anak termasuk dalam melihat, mendengar, dan berpikir selama proses belajar. Baker (2008) mengatakan bahwa menyelamatkan anak supaya tidak pendek (stunting) sangat penting, sebab terkait dengan kecerdasan dan produktivitas kerjanya kelak sebagai generasi penerus bangsa.

Dari hasil analisis regresi tersebut diperoleh persamaan dampak stunting $(X)$ terhadap prestasi belajar ( $(Y)$ yaitu:

$$
Y=8.117+0.444 X\left(R^{2}=0.234 ; p=0.00\right)
$$

Berdasarkan persamaan regresi diatas dapat disimpulkan bahwa setiap kenaikan status gizi TB/U anak sebesar 1 SD maka prestasi belajar anak akan naik sebesar 0.444. Begitu pula sebaliknya, setiap penurunan status gizi TB/U anak sebesar 1 SD maka prestasi belajar anak akan turun sebesar 0.444. Setelah dilanjutkan dengan uji t diketahui bahwa 
stunting berdampak sangat signifikan terhadap prestasi belajar anak. Hal ini ditandai dengan nilai t hitung dari variabel stunting sebesar 6.053 dengan signifikasi 0.00. Penelitian Yustika (2006) pada siswa SD di Kecamatan Samalantan, menunjukkan bahwa ada hubungan yang signifikan antara stunting dengan prestasi belajar anak sekolah $(p<0.05)$. Stunting membuat kemampuan berpikir dan belajar siswa terganggu dan akhirnya kehadiran dan prestasi belajar siswa akan menurun dibandingkan dengan anak non stunting.

Usia sekolah dasar merupakan usia emas kedua bagi pertumbuhan anak baik fisik maupun mental yang berpengaruh bagi masa depan. Keadaan gizi kurang seperti stunting yang dialami oleh anak usia sekolah akan memengaruhi kemampuan daya tangkap anak dalam mengikuti pelajaran di sekolah dan akan memengaruhi prestasi belajarnya. Hasil penelitian ini didukung oleh pendapat Almatsier (2001) yang mengatakan bahwa kekurangan gizi dapat berakibat terganggunya fungsi otak secara permanen.

Menurut Slameto dalam Ewintri (2012), prestasi belajar yang dicapai seorang siswa merupakan hasil interaksi dari berbagai faktor yang memengaruhinya baik dari dalam diri (faktor internal) maupun dari luar (faktor eksternal). Faktor internal yaitu keadaan fisik dari anak tersebut yang dipengaruhi oleh status gizi dan kesehatannya serta keadaan psikis seperti inteligensi, perhatian, minat, bakat, motif, kematangan, dan kesiapan.

Faktor eksternal yaitu faktor dari luar individu atau siswa yang terdiri dari: 1) faktor keluarga yang meliputi cara orang tua mendidik, relasi antara anggota keluarga, suasana rumah, dan keadaan ekonomi keluarga; 2) faktor sekolah, antara lain metode mengajar guru, kurikulum, relasi guru dengan siswa, relasi siswa dengan siswa, disiplin sekolah, alat pelajaran, waktu sekolah, standar belajar diatas ukuran, keadaan gedung, metode belajar dan tugas rumah; 3) faktor masyarakat (kegiatan siswa dalam masyarakat, media massa, teman bergaul, dan bentuk kehidupan masyarakat).

\section{KESIMPULAN}

Determinan kejadian stunting adalah pendapatan keluarga, pengetahuan gizi ibu, pola asuh ibu, riwayat infeksi penyakit, riwayat imunisasi, asupan protein, dan pendidikan ibu. Faktor risiko kejadian stunting yakni pendapatan keluarga, ibu bekerja, pengetahuan gizi dan pola asuh ibu, memiliki riwayat infeksi penyakit, tidak memiliki riwayat imunisasi yang lengkap, dan asupan protein rendah. Sedangkan pendidikan ibu rendah merupakan faktor protektif kejadian stunting. Terdapat indikasi stunting berpengaruh terhadap prestasi belajar anak.

Sampai saat ini masih dicurigai faktor kekurangan iodium sebagai salah satu penyebab ting- ginya masalah stunting. Oleh karena itu, diharapkan penelitian lanjutan hendaknya mempertimbangkan analisis pada faktor asupan iodium dan hubungannya dengan kejadian masalah stunting.

\section{DAFTAR PUSTAKA}

Adar LS \& Guilkey DK. 1997. Age spesific determinant of stunting in Filipina children. The Journal of Nutrition, 127(2).

Aditianti. 2010. Faktor determinan stunting pada anak usia 24-59 di Indonesia. Info Pangan dan Giz, 19(2), 42-43.

Adisasmito W.2007. Hubungan Pola Asuh Ibu dengan Status Gizi Ibu pada Keluarga Sejahtera dan Pra Sejahtera [Skripsi]. Fakultas Kesehatan masyarakat, Universitas Sumatera Utara, Sumatera Utara.

Almatsier S. 2001. Prinsip Dasar Ilmu Gizi. Cetakan ke-5. Gramedia Pustaka Utama, Jakarta.

Astri LD, Nasution A, \& Dwiriani CM. 2006. Hubungan konsumsi ASI dan MP-ASI serta kejadian stunting anak usia 6-12 bulan Di Kabupaten Bogor. Media Gizi dan Keluarga, 30(1), 15-23.

Baker J. 2008. Strategies for Improving Nutrition of Children. http://www.globalhealth.org (11 Juli 2012)

Berg A. 1986. Peranan Gizi dalam Pembangunan. Penerbit Rajawali, Jakarta.

Bora NGB, Picauly I, \& Aspatria U. 2012. Analisis determinan stunting dan dampaknya terhadap prestasi belajar anak sekolah dasar di Kecamatan Kota Waingapu Kabupaten Sumba Timur. Jurnal Pangan, Gizi, dan Kesehatan Masyarakat, 4(3), 1100-1110.

Departemen Kesehatan RI. 2008. Laporan Riset Kesehatan Dasar Provinsi Nusa Tenggara Timur Tahun 2007. www.scribd.com/Laporan_Hasil_Riskesdas_NTT_2007.pdf (15 Desember 2011).

Fanggi A C, Picauly I, \& Jutomo L. 2012. Studi perbandingan indeks prestasi belajar antara siswa SD yang mengalami stunting dan non stunting di Kota Kupang. Jurnal Gizi dan Kesehatan Masyarakat, 4(2), 1106-1116.

Fikhar A. 2003. Faktor Determinan KEP pada Anak Usia 6 Bulan-3 Tahun di Kecamatan Kuranji Kota Padang Tahun 2003. Program Pascasarjana UI, Jakarta.

Husaini MA, Karyadi L, Husaini YK, Karyadi D, \& Pollit E. 2000. Developmental Effects of Shortterm Suplementary Feeding in Nutritionally at risk Indonesian Infant. Am.J.Clin.Nutr, 45

Kusharisupeni. 2002. Peran Status Kelahiran terhadap Stunting pada Bayi. Jurnal Kedokteran, 23, 73-80.

Kusumaningrum R, Manongga SP, \& Picauly I. 2013. Determinan Penyimpangan Positif (PD) Status 
Gizi Anak Balita Keluarga Miskin Suku Bangsa Dawan Di Kabupaten TTS [Skripsi]. Fakultas Kesehatan Masyarakat Universitas Nusa Cendana, Kupang NTT.

Lana HMY, Manongga SP, \& Jutomo L. 2012. Studi komparatif pertumbuhan dan perkembangan anak balita pada beberapa tipologi wilayah di Kabupaten Timor Tengah Selatan, Jurnal Gizi dan Kesehatan Masyarakat, 4(2), 1165-1183.

Mahgoub SEO, Nyepi M, Bandeke T. 2006. Factors affecting prevalence of malnutrition among children under three years of age in Botswana. African Journal of Food, Agriculture, Nutrition and Development. Rural Outreach Program, 6(1). (11 Juli 2012).

Nasikhah R \& Margawati A. 2012. Faktor resiko kejadian stunting pada balita usia 24-36 bulan di Kecamatan Semarang Timur, Journal of Nutrition College, 1(1), 176-184.

Nubatonis YR, Manongga SP, \& Candra Dewi R. 2012. Hubungan pola asuh ibu dengan status gizi anak usia balita di Kabupaten Timor Tengah Selatan. Jurnal Gizi dan Kesehatan Masyarakat, 4(1), 1091-1105.

Notoadmdjo S. 2005. Metodologi Penelitian Kesehatan. Rineka Cipta, Jakarta.

Oematan G \& Aspatria U. 2013. Faktor-faktor penentu kejadian gizi buruk stunting di daerah dengan karakteristik pertanian lahan kering Kabupaten Kupang. Provinsi Nusa Tenggara Timur, Jurnal Pangan, Gizi, dan Kesehatan, 5(1), 725-736.

Ramli, Kingsley EA, Inder KI, Bowe SJ, Jacobs J, \& Dibley MJ. 2009. Prevalensi and risk factors for stunting and severe stunting among under five in North Maluku Province of Indonesia. BMC Pediatric (internet). (citied2013 Oktober 23) available from: http://www.ncbi.nlm.nih.gov.

Renyoet BS, Hadju V, \& Rochimiwati SN. 2012. Hubungan pola asuh dengan kejadian stunting anak usia 6-23 bulan di wilayah pesisir Kecamatan Tallo Kota Makassar. Jurnal Nutrient Science (PA-NSC), hal. 1-13.

Ridwan. 2008. Kegiatan Belajar terhadap Prestasi yang dicapai, (on-line) http://ridwan202. wordpress.com20080423kegiatan-belajar-danprestasi.htm, diakses 9 November 2008.

Riyadi H, Khomsan A, Sukandar D, Faisal A \& Mudjajanto ES. 2006. Studi tentang status gizi pada rumah tangga miskin dan tidak miskin. Jurnal Indonesia Food, 29(1), 33-46.
Riyanto A. 2012. Penerapan Analisis Multivariat dalam Penelitian Kesehatan. Nuha Medika, Yogyakarta.

Saryono 2009. Metodologi Penelitian Kesehatan Penuntun Praktis bagi Pemula. Mitra Cendikia Press, Yogyakarta.

Salimar. 2009. Karateristik Masalah Pendek (Stunting) pada Balita di Seluruh Wilayah Indonesia. Info Pangan dan Gizi, 19 (2),15-16.

Sawadogo, Prosper S, Martin-Prevel, Yves, Savy, Mathilde, Kameli, Yves, Traissac, Pierre, Traore, S. Alfred \& Delpeuch, Francis. 2006. An Infant and Child Feeding Index Is Associated with the Nutritional Status of 6-to 23-MonthOld Children in Rural Burkina Faso. Community and International Nutrition. [Online]. 136., p. 656-663. http://jn.nutrition.org/ content/136/3/ 656.full.pdf [diakses 23 Oktober 2013].

Slameto. 2003. Belajar dan Faktor-Faktor yang Mempengaruhinya. Rineka Cipta, Jakarta.

Setiati R. 2006. Hubungan Pengetahuan Sikap dan Praktek Pola Asuh Ibu dengan Status Gizi Anak Balita [Skripsi]. Fakultas Kesehatan Masyarakat Universitas Diponegoro, Malang.

Semba RD, de Pee S, Sun Kai, Sari M, Akhter N, \& Bloem MW. 2008. Effect of parental formal education on risk of child stunting in Indonesia and Bangladesh: a Cross-Sectional Study. Lancet, 371, 322-328.

Sunita A. 2003. Prinsip Dasar Ilmu Gizi. Edisi pertama. PT Gramedia Pustaka Utama, Jakarta.

Supariasa, IDN, Bakri B, \& Fajar I. 2002. Penilaian Status Gizi. Buku Kedokteran EGC, Jakarta.

Yustika S. 2006. Hubungan antara status gizi dengan nilai evaluasi murni SD Kecamatan Samalantan Kabupaten Bengkayang Propinsi Kalimantan Barat. Jurnal Kemenkes Poltekkes Yogyakarta 2012. http: / /jurnal.poltekkesjogja.ac.id/ (14 September 2012).

Zere E \& McIntyre D. 2003. Inequities in under-five child malnutrition in South Africa. Asia Pasific Journal, (2), 125-127.

Zottareli LK, Sunil TS, \& Rajaram. 2007. Influence of Parental and Sosioecenomic Factor on Stunting in Children Under 5 Years in Egypt. Eastern Mediteranean Health Journal (internet). (cited 2013 Oktober 23) available from : http:// www.emro.who.int/emhj/1306. 